\title{
Recharacterization of Synapterpes (S.) hanleyi (Pfeiffer) (Mollusca, Gastropoda, Stylommatophora, Subulinidae) ${ }^{1}$
}

\author{
Norma Campos Salgado ${ }^{2}$ \\ Arnaldo C. dos Santos Coelho ${ }^{2}$
}

\begin{abstract}
Synapterpes (S.) hanleyi (Pfeiffer, 1846) is characterized by anatomy, synonymy and geographical distribution. Shell and soft parts were studied and important taxonomic characters evaluated and illustrated. These studies give conditions to characterize the species and include it in the genus Synapterpes Pilsbry, 1896 and distinguish $S$. hanleyi from the other species of Synapterpes s.s. known only by their shells, respectively from Brazil and Colombia: $S$.(S.) coronatus (Pfeiffer, 1846) and S.(S.) wallisi (Mousson, 1869).
\end{abstract}

KEY WORDS. Mollusca, Gastropoda, Stylommatophora, Synapterpes hanleyi, taxonomy, conchology, Brazil

This article is part of the project on Brazilian landsnails developed by the authors in order to ally what is known about shells with the new data of jaw, radula and soft parts that increase the species characterizations.

In this opportunity it was obtained and studied living material of Synapterpes hanleyi, described originally as Bulimus Scopoli, 1788 and designated as type-species of Synapterpes Pilsbry, 1896.

\section{MATERIAL AND METHODS}

Material is deposited in Mollusk Collections of Museu Nacional, Universidade Federal do Rio de Janeiro (MNRJ), Brazil, and Natur-Museum Senckenberg, Frankfurt a.M. (SMF), Germany.

BRASIL: 1 shell, leg./date? (SMF 157248); ESTADO DO RIO DE JANEIRO, Município de Terezópolis, Serra dos Órgãos, 1 specimen, M. S. Pena \& W. Krien leg., 01/V/1991 (MNRJ 7179); Município do Rio de Janeiro, Floresta da Tijuca, Estrada D. Castorina, 1 young specimen, 1 shell, 1 radula, 1 jaw, 2 roofs of palial cavity, 1 digestive and 2 reproductive systems, C. A. Caetano leg., 16/XI/1993 (MNRJ 7180) and 1 soft part, 1 young "Pfeiffer gland", C.A. Caetano, leg., 05/I/1994 (MNRJ 7181).

1) Contribuição número 69, Malacologia, Departamento de Invertebrados, Museu Nacional, Universidade Federal do Rio de Janeiro, Rio de Janeiro, Brasil. Com auxílios do Conselho Nacional de Desenvolvimento Científico e Tecnológico (CNPq) e Fundação Universitária José Bonifácio (FUJB).

2) Departamento de Invertebrados, Museu Nacional. Quinta da Boa Vista, São Cristóvão, 20940-040 Rio de Janeiro, Rio de Janeiro, Brasil. Bolsista do CNPq.

E-mail: nsalgado@openlink.com.br. 
The shells have been measured (height and width) with Kanon Caliper Rule (Hardened Stainless $1 / 20 \mathrm{~mm}$ ) and the number of whorls determined according to DIVER (1931). The radula and jaw have been prepared according to JURBERG's (1964) technique. Anatomic exam of soft parts whose samples have been captured alive was done with technique described in SALGADO et al. (1995). The anatomic pieces have been treated by the usual staining technique of acetic carmine and diaphanization with creosote. Shells and soft parts have been studied, drawn and photographed under the Wild M5 Stereoscope with magnifying glass, the Wild M20 Microscope with connected clearing cameras and Canon F1, Macro Lens FD 50mm $1: 3.5$.

\section{RESULTS \\ Synapterpes Pilsbry, 1896}

Synapterpes Pilsbry, 1896: 46; 1906: 228-229. - Zilch, 1959: 356.

? Synapterpes Pilsbry, 1896. - Thiele, 1931: 554-555.

Type-species. Bulimus hanleyi Pfeiffer, 1846.

Geological and Geographic distributions. Recent; Brazil, Colombia, Ecuador (ZILCH 1959).

Diagnosis. The shell is thin, and has elongated-oval shape and obtuse apex. The protoconch is either smooth or with axial striae. The aperture is oblong-oval or elongated, with thin outer lip. The columella is slender and rectilineal in upper part whereas it's concave, not truncate in the lower one.

\section{Subgenus Synapterpes}

Synapterpes (subgenus); Pilsbry, 1906: 228-230. - Thiele, 1931: 555. - Zilch, 1959: 356.

Geographical distribution. Brazil, Colombia (PILSBRY 1906; THIELE 1931; ZILCH 1959).

Diagnosis. The protoconch is relatively small and smooth. Its aperture is oblong-oval. The lower part of the columella is entire.

Species included in Synapterpes s.s.: S. hanleyi (Pfeiffer, 1846), S. coronatus (Pfeiffer, 1846) to Brazil and S. wallisi (Mousson, 1889) to Colombia (PILSBRY 1906).

\section{Synapterpes (Synapterpes) hanleyi (Pfeiffer, 1846)}

Bulimus hanleyi Pfeiffer, 1846: 111, pl.4, fig. 2. - Pfeiffer, 1848: 171. - Reeve, 1848: pl.30, sp. 181. Binney \& Bland, 1871: 208.

Bulimus (Oxicheilus) hanleyi; Albers, 1850: 174

Bulimus (Orphnus) hanleyi; Martens, 1860: 193.

Achatina subemarginata Deshayes 1851: 187, pl. 134, figs 31-32, apud Pilsbry, 1906: 229.

Oleacina subemarginata; Tryon, 1885: 35, pl.6, fig. 77, apud Pilsbry, 1906: 229.

Synapterpes (Synapterpes) hanleyi; Pilsbry, 1906: 228-229, pl. 37, figs 87-88. - Thiele, 1931: 554.Zilch 1959: 356, fig. 1311.

Synapterpes hanleyi; Lange-de-Morretes, 1949: 133.

Type-locality. "Brasilia (Miller)" (PFEIFFER 1846).

Diagnosis. The shell is uniformly reddish brown and elongated-oval with an 
obtuse apex. It has longitudinal striae at the impressed suture. The body whorl is $2 / 3$ the total height. The aperture is oblong-oval with a slightly reflexed columellar lip. In the reproductive system the folds of the uterus are distinct and innumerable, the base of penial complex has notable digitiform structure.
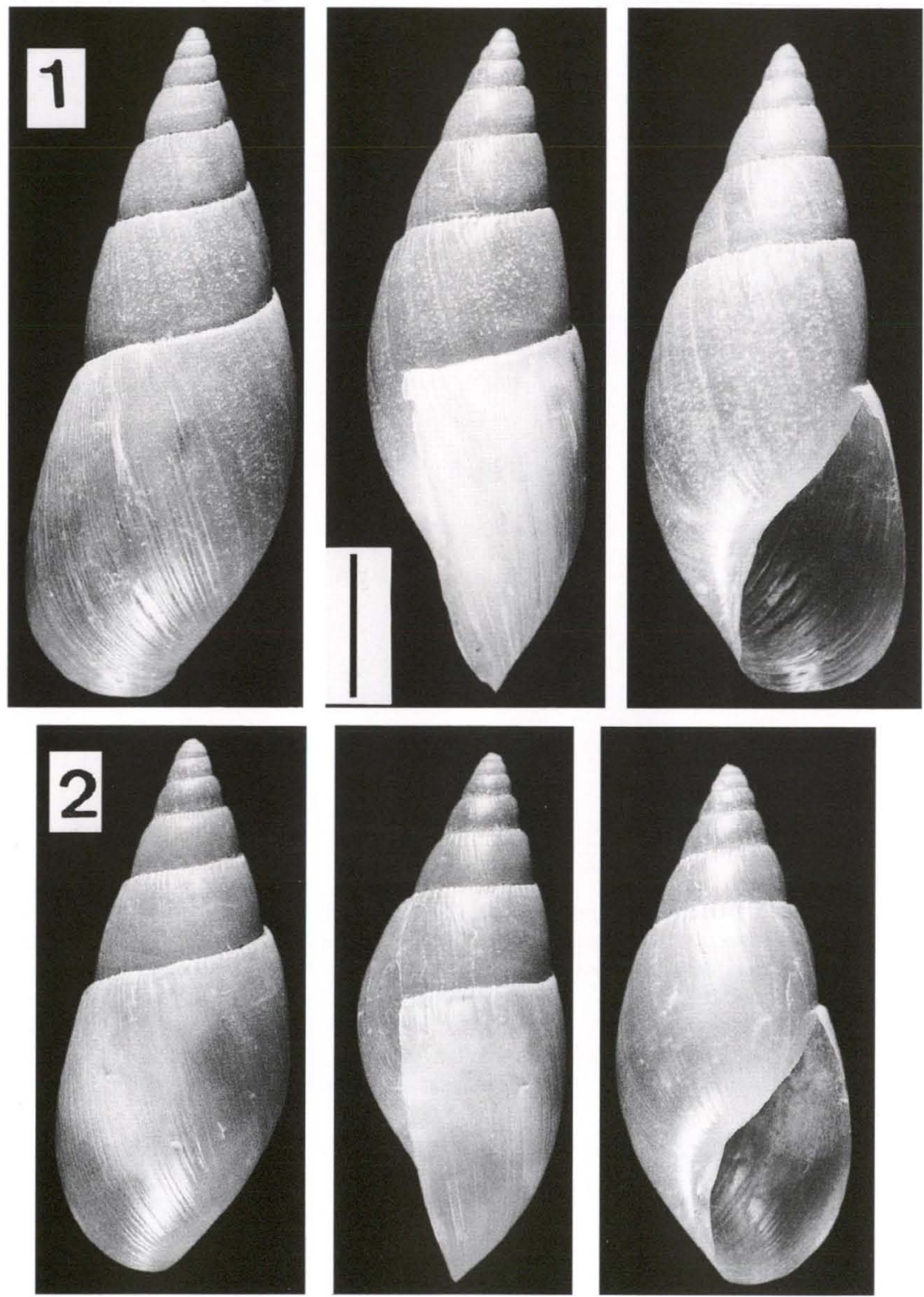

Figs 1-2. Synapterpes (Synapterpes) hanleyi, shell. (1) Adult, MNRJ 7180; (2) young, MNRJ 7179. (bar 10mm). P.M.S. Costa photo. 

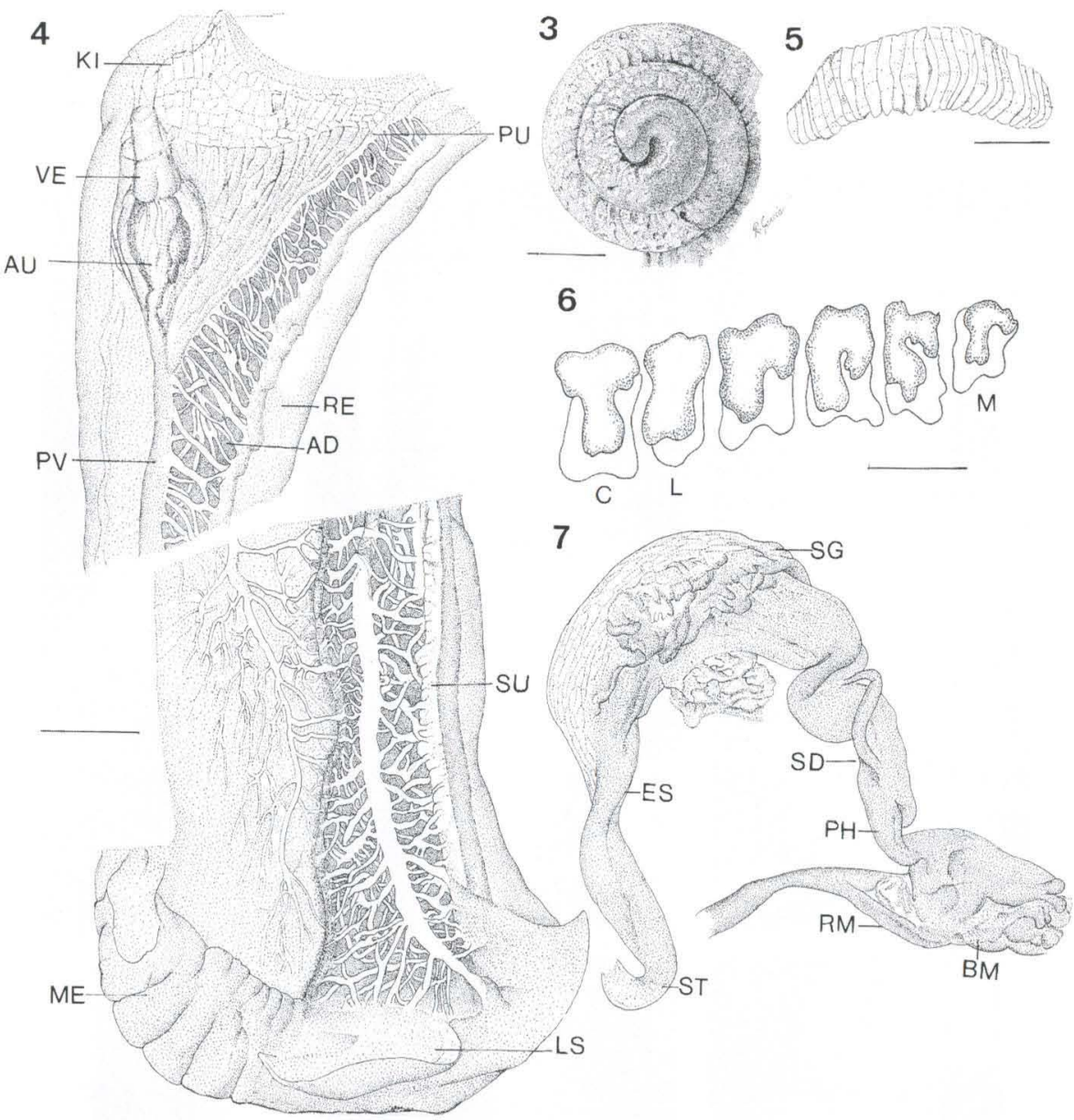

Figs. 3-7. Synapterpes (Synapterpes) hanleyi. (3) Protoconch, MNRJ 7180 (bar $1 \mathrm{~mm}$ ); (4) roof of palial cavity, seen by transparence, MNRJ 7180 (bar $5 \mathrm{~mm}$ ); (5) jaw (bar $1 \mathrm{~mm}$ ); (6) Radula (bar 0,1mm); (7) digestive system (bar 3mm), MNRJ 7180. (AD) Ad-rectal area, (AU) auricule, (BM) bucal mass, (C) central tooth, (ES) esophagus, (KI) kidney, (L) lateral tooth, (LS) laminar structure, $(M)$ marginal tooth, $(M E)$ mantle edge, $(P)$ pericardium, $(\mathrm{PH})$ pharynx, $(\mathrm{PU})$ primary ureter, (PV) pulmonar vein, $(\mathrm{RB})$ radular bulb, $(\mathrm{RE})$ rectum, $(\mathrm{RM})$ radular muscle, $(\mathrm{SD})$ salivar duct, (SG) salivar glands, (ST) stomach, (SU) secondary ureter, (VE) ventricle.

Characterization. Shell (Figs 1-3): it is thin, translucent, bright, elongatedoval, uniformly reddish-brown. It has $71 / 2$ whorls and a slight convex profile, $48 \mathrm{~mm}$ high and $20 \mathrm{~mm}$ wide. The protoconch is smooth, bright-brown, with $13 / 4$ whorl. The teleoconch has regular and longitudinal striae; at the impressed, crenulated suture they are oblique. The periostracum is thin and adherent. The body whorl is $2 / 3$ as long as the total height and the aperture is oblong-oval with a thin outer lip and slightly reflexed columellar lip. 


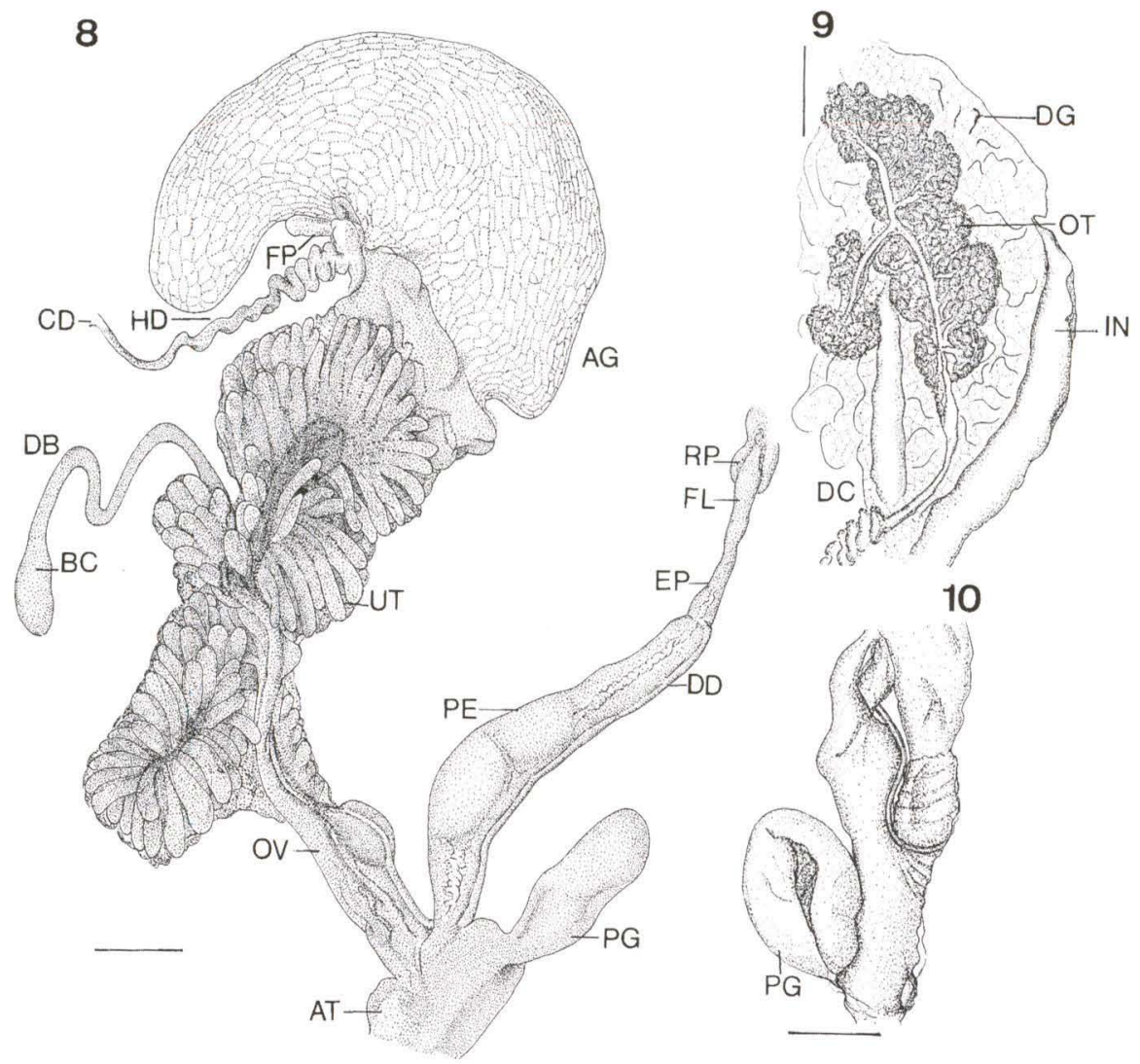

Figs 8-10. Synapterpes (Synapterpes) hanleyi. (8) Reproductive system, MNRJ 7180 (bar $3 \mathrm{~mm}$ ); (9) ovotestis, MNRJ 7180 (bar $2 \mathrm{~mm}$ ); (10) Pfeiffer gland' of young specimen (bar $2 \mathrm{~mm}$ ). (AG) Albumen gland, (AT) atrium, (BC) bursa copulatrix, (BD) bursa duct, (CD) collector duct, (DD) deferent duct, (DG) digestive gland, (EP) epiphallus, (FC) fertilization complex, (FL) flagellum, (HD) hermaphrodite duct, (IN) intestine, (OT) ovotestis, (OV) oviduct, (PE) penis, (PG) Pfeiffer gland', (PR) prostate, (RP) retractor of penis, (UT) uterus.

Soft parts, jaw and radula (Figs 4-10). The reddish-brown headneck has two horizontal dark-brown bands in the upper region.

The mantle edge is developed with a long laminar structure covering the pneumostome. The roof of the palial cavity (Fig. 4) is long and wide with evident vascularization and pigmentation, in the area between the ureters and the pulmonary vein (ad-retal); kidney triangular and elongated, surpassing the pericardium, which has developed an auricle and a ventricle; the primary ureter is evident as is the secondary one, which is closed.

Digestive system (Figs 5-7). It has a developed buccal mass with a protruding digitiform radular bulb. The pharynx is short and narrow, while the salivary glands are located in the upper part of esophagus, one in front of other, with long ducts. 
The stomach with thick muscles at the piloric region is small followed by the long intestine (Fig. 7). The jaw is striated, lightly chitinized with 28 plates without pigmentation (Fig. 5). The radula has 83 teeth per row (41.1.41); the central tooth is symmetrical with rectangular base, tricuspid with a long mesocone and short ectocones; lateral teeth are long, with larger internal cusps than external ones, until the $26^{\text {th }}$ tooth; the marginal teeth are smaller (Fig. 6).

Reproductive system (Figs 8-10). The ovotestis is developed with 18 groups of follicles succeeded by a collector duct and a hermaphrodite duct coiled in the distal region (Fig. 9). The fertilization complex is developed with accentuated expansion at the free edge. The uterus has many deep, digitiform folds and ranges from yellow to red; the prostate is compacted, grayish in colour and smooth which is followed by the developed free oviduct (Figs 8-9). The duct of bursa copulatrix is very long and regular in diameter. The deferens duct emerges up to the free oviduct bifurcation, level with the duct of the bursa. It runs to the penial complex and projects itself to the interior of the epiphallus without papilla. The long penis extends twice the length of epiphallus plus the flagellum size and has a thin sheath. The short epiphallus and the long flagellum are completely enveloped by the retractor muscle of the penis. There is a glandular structure (Pfeiffer gland) in the base of the penis, digitiform in adult specimens and oval in young ones (Figs 8, 10).

\section{DISCUSSION AND CONCLUSIONS}

The conchological diagnostic characters observed in Synapterpes (Synapterpes) hanleyi, S. (S.) coronatus and S. (S.) wallisi allowed us to consider these species in the same genus and subgenus.

Synapterpes hanleyi (apud PILSBRY 1906: 228-229, pls. 36-37, figs 87-90) differs from $S$. coronatus in the following ways: waxen-yellowish shell, obtuse apex, measuring in height $21 \mathrm{~mm}$ and in width $7,5 \mathrm{~mm}$, with small and whitish axial tubercles at the suture; the aperture is oval with developed columellar calum. It differs from $S$. wallisi by very thin and whitish shell, in height $26 \mathrm{~mm}$ and in width $12 \mathrm{~mm}$, with imperfect and decussating striae; hard, wide, oblique aperture with short columellar calum.

PILSBRY (1906: 228) commented that BINNEY \& BLAND (1871:208) described the jaw and the radula of "hanleyi" and later BINNEY (1874: 62, pl.6, fig. 5) illustrated its teeth as similar to Strophocheilus ones. However according to PILSBRY (1906) the conchological characters were so different that he concluded that the radula may have been misrepresented.

The description of the jaw and radula made by BINNEY \& BLAND (1871) to "B. hanleyi Pfr collected in Brazil, by Mr. G. Anthony" agrees with the characterization presented and illustrated in this article.

It is necessary to collect more specimens in order to research the microanatomy of the glandular and digitiform structure at the base of the penis that seems to be similar to "Pfeiffer gland", described by Simroth (1912: 555) to "C. [onulus] semen lini", to Brazil, "C. fulvus Ihering" to Europe and "C. tener Jacobi" to Japan. 
ACKNOWLEDGMENTS. We are grateful to Paulo Marcio Santos Costa, postgraduate student of Zoology at Museu Nacional/UFRJ, for the photos.

\section{REFERENCES}

ALBERS, J.C. 1850. Die Heliceen, nach natürlicher Verwandtschaft systematisch geordnet. Berlin, Th. Chr. Fr. Enslin, 262p.

BINNEY, W.G. 1874. On the anatomy and lingual dentition of Ariolimax and other pulmonata. Proc. Acad. Nat. Sci. Philad.: 33-62.

BINNEY, W.G. \& T. BLAND. 1871. Notes on lingual dentition; n.2. Amer. Journ. Conch., Philadelphia, 6 (3): 202-215.

DESHAYES, G.P. 1851. Histoire Naturelle des pulmonés sans opercule. 2, Part. 2, p. 1-245. In: D. FÉRUSSAC \& G.P. DESHAYES (Eds). Histoire naturelle générale et particulière des Mollusques terrestres et fluviatiles. Paris, J.B. Baillière, Part. 1, XVI+184p.

DIVER, C. 1931. A method of determining the number of the whorls of the shell and its application to Cepaea hortensis Mull. Proc. Malac. Soc. Lond. 19: 234-239.

JuRBERG, P. 1964. Sobre Auris bilabiata melanostoma (Moricand, 1836) (Gastropoda, Pulmonata, Bulimulidae). Mem. Inst. Oswaldo Cruz, Rio de Janeiro, 62: 81-94.

LANGe-De-Morretes, F. 1949. Ensaio de catálogo dos moluscos do Brasil. Arq. Mus. paran., Curitiba, 7 (1): 5-216.

MARTENS, E. VON. 1860. Die Heliceen, nach natürlicher Verwandtschaff systematisch geordnet. Von Joh. Christ. Albers, Zweite Ausgabe, nach dem hinterlassen Manuskript besorgt von Eduard von Martens. Leipzig, WiIhelm Engelmann, XVIII+359p.

Mousson, A. 1869. Notiz über einige von Herrn Gustav Wallis aus dem nordlichen Südamerika zurückgebrachte Mollusken. Malakozool. Bl., Cassel, 16: 170-189.

Pfeiffer, L. 1846. Bulimus, p.111-116, pl. 4. In: R.A. PHILIPPI (Ed.). Abbildung und Beschreibungen neuer oder wenig bekannter Conchylien. Cassel, Theodor Fisher, vol. 2, 231p.

- 1848. Monographia heliceorum viventium. Lipsiae, F.A. Brockhaus, vol. 2, 594p.

Pilsbry, H.A. 1896. Note on Bulimus hanleyi and B. coronatus. The Nautilus, Philadelphia, 10 (4): 37-48.

. 1906. In: G.W. TRYON JR. \& H.A. Pilsbry (Ed.). Manual of Conchology. Second series: Pulmonata. Philadelphia, Conchological Department, Academy of Natural Sciences of Philadelphia. 18 (69): 1-64, pls.1-10; (70):65-160, pls.11-20; (71):161-272, pls.21-34 (1906); (72): 273-357+XII.

ReEVE, L.A. 1848-1850. Monograph of the genus Bulimus., p.XI, 89 pls. In: Conchologia Iconica. London, Reeve, Benham and Reeve, vol. 5.

SALGADO, N.C.; A.C.S. CoElHo \& H.M. BARROS. 1995. Macroanatomia, microanatomia e histologia do sistema reprodutor de Thaumastus (Thaumastus) taulnaisii (Férussac,1822), T. (T.) magnificus (Grateloup, 1839) e T.(T.) achilles (Pfeiffer, 1852) (Mollusca, Gastropoda, Bulimulidae) Bol. Mus. Nac., n.s. 
Zool., Rio de Janeiro (358): 1-46.

Simroth, H. 1912. Mollusca (Weichtiere), p.555-556. In: H.G. BronN's (Ed.). Klassen und Ordnungen des Tier-Reichs. Leipzig, C. F. Winter'sch, 3 (2): 545-608.

THIELE, J. 1929-1931. Handbuch der systematischen Weichtierkunde. Jena, Gustav Fischer. 1 (1): 1-376 (1929), (2): 377-778 (1931).

TrYoN JR., G.W. 1885. Manual of Conchology. Second series: Pulmonata.

Philadelphia, Conchological Section of the Academy of Natural Science of Philadelphia. 1: 5-364.

Zilch, A. 1959. Euthyneura, Subulinidae, p.342-363. In: O.H. SHINDEwOlF (Ed.).

Handbuch der Paläozoologie. Berlin, Nikolasse, Gebrüder Bontraeger, vol. 6, 2 (1): 1-200 (2): 201-400.

Recebido em 19.XII.1997; aceito em 13.V.1999 